\title{
The Expression of TGF- $\beta 1$, p38 MAPK, and ERK-1 Protein in Cleft Affected Tissue of the Lip: An Observational Study
}

\author{
Herman Yosef Limpat Wihastyoko', Erdo Puncak Sidarta² \\ ${ }^{1}$ Department of Plastic and Reconstructive Surgery, Faculty of Medicine, Universitas of Brawijaya/Dr. Saiful Anwar \\ General Hospital, Malang, Indonesia \\ ${ }^{2}$ Faculty of Medicine, Universitas Brawijaya, Jl. Veteran, Malang, Indonesia
}

Background: Cleft lip is a congenital birth defect caused by many proteins. Transforming growth factor (TGF)- $\beta 1$, p38 mitogen-activated protein kinase (MAPK) and extracellular signal-regulated protein kinase (ERK)-1 are proteins which regulate proliferation and apoptosis role during intrauterine period. This study aimed to observe the expression of these proteins in cleft affected tissue of the lip.

Materials and Methods: A descriptive study by examining the TGF- $\beta 1$, p38 MAPK, and ERK-1 immunohistochemical expression of cleft affected tissue of the lip was conducted. Subjects were patients that were participating for the social event held by Plastic Surgery Department, Faculty of Medicine, Univesitas Brawijaya, on December 3-12, 2012 in Nusa Tenggara Timur. Excess lip mucosa (waste tissue) during the operation were stored in $10 \%$ formalin then stained by immunohistochemistry for TGF- $\beta 1$, p38 MAPK, and ERK-1. We counted the average protein expression under the light microscope with 1000x magnification for 20 different fields of view, randomly.

Results: Paraffin blocks from 30 subjects were selected. The mean p38 MAPK expression was found to be highest, with the average of 8 per field of view; followed by the mean TGF- $\beta 1$ expression, with the average of 5 per field of view; and the mean ERK-1 expression was found to be the lowest, with the average of 2 per field of view.

Conclusion: Expression of $\mathrm{p} 38$ MAPK and TGF- $\beta 1$ are higher than ERK- 1 , suggesting that $\mathrm{p} 38$ MAPK is in the same signalling pathway as TGF- $\beta 1$, while ERK-1 is lower, as its role as anti-apoptotic. This is consistent with several previous studies showing that all proteins took part in the development of cleft lip or craniofacial development. Further study needs to be conducted to determine which protein plays the bigger role.

Keywords: cleft lip, TGF-81, p38 MAPK, ERK-1

\section{Introduction}

Cleft lip is one of the most common birth defects that caused by multifactorial morpho pathogenesis, it also known that over 500 different complex genetic disorders contributes in this condition. ${ }^{1}$ Some studies has been conducted in order to identified the common cause of this birth defect, genome scan and association studies have reported almost 37 risk

Date of submission: December 21, 2020

Last Revised: March 24, 2021

Accepted for publication: April 8, 2021

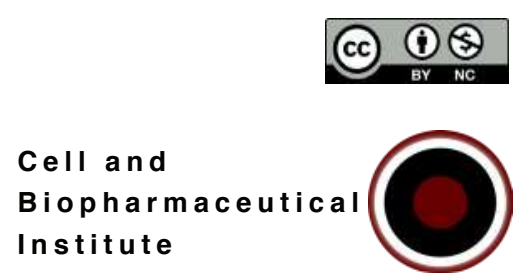

Corresponding Author:

Erdo Puncak Sidarta

Faculty of Medicine, Universitas Brawijaya

Jl. Veteran, Malang 65145, Indonesia

e-mail: erdo.ps@gmail.com 
genes/loci, but the major cause of this cleft lip with or without palate still unclear due to the possibility of gene and environmental interaction. ${ }^{2}$ The incidence is vary from every region. In Africa is about 1:3000 in every birth, 1:5000 in Europe, 1:3500 in Asia, and 1:150 in American Indians, while in Indonesia the incidence is 2:1000 in every birth. ${ }^{3,4}$ A retrospective study conducted in West Java, Indonesia during 2011 and 2015 shows the total 1596 patients and $20.08 \%$ are known with the family history of cleft lip. ${ }^{5}$

Transforming growth factor (TGF)- $\beta 1$ takes part in controlling proliferation, differentiation and survival in various cell type. TGF- $\beta 1$ also contributes in burn scar contracture and modulates wound inflammation and granulation tissue formation. ${ }^{6,7}$ TGF- $\beta 3$ has low expression in gland and epithelium of unaffected cleft of lip and all TGF- $\beta$ isoform known to have role in palatogenesis. ${ }^{8}$ Meanwhile TGF- $\alpha$ is known to expressed minimally in cleft lip and palate and normal lip, this indicates its role on the disease. $^{9}$

The p38 mitogen-activated protein kinase (MAPK) has role in mediating the signalling of TGF- $\beta$ from Smadindependent pathway and responsible in cell regulation, specifically in craniofacial development. The p38 MAPK activation disturbs cell during development process, prior studies showed the increasing in p38 MAPK activation can be used as indicator of incomplete development in craniofacial region. The mechanism of p38 MAPK is by inhibiting the cell proliferation resulting to apoptosis of the cell and causing the condition such as cleft lip. ${ }^{10}$

Extracellular signal-regulated protein kinase (ERK)-1 play roles as anti-apoptosis and initiate cell proliferation and differentiation from embryonic stem cell. ${ }^{11}$ The extracellular signals to cytoplasmic and nuclear effector transmitted via MAPKKK (RAF), MAPKK (MEK1/2) and MAPK (ERK) which resulting ERK dimers to regulates the target in the cytosol, nucleus and the serum response factor (SRF). The inactivation in ERK-2, as well as the upstream components of the ERK cascade resulted in analogous craniofacial malformation to those in human. ${ }^{12}$ The aim of this study is to detect the TGF- $\beta 1$, p38 MAPK, and ERK-1 protein expression in human with cleft lip specifically in Indonesian population to provide data to be used for further study.

\section{Materials and methods}

This research was a descriptive study which examined the TGF- $\beta 1$, p38 MAPK, and ERK-1 immunohistochemical expressions of cleft lip mucosa. This study was approved by the Ethics Committee of Universitas Brawijaya (No. 465/EC/KEPK-S1-PD/10/2013) to use the stored biological material of excess tissue of cleft affected tissue mucosa from the social event held in 2012.

\section{Sample Collection}

The stored biological material samples were obtained from the excess tissue of the lip mucosa with 2-3 mm thickness from the reconstruction plastic procedure of the cleft lip without cleft palate at Alor Hospital, Larantuka Hospital, Kupang General Hospital, during social event held by Plastic Surgery Department, Faculty of Medicine, Universitas Brawijaya on December 3-12, 2012. There were total of 30 patients, consist of 16 men and 14 women, with age ranged from 5 months old to 29 years old. The excess tissues were put in a small tube containing formalin to preserve the tissue, then stored in the cooling box before being delivered to Biochemistry Laboratory of Universitas Brawijaya to be stored inside the cooling storage.

\section{Immunohistochemistry}

The paraffin blocks for each of the samples were sliced with the thickness of 4-mm, then deparaffinized and its antigen was retrieved. After being washed with phosphate buffered saline (PBS), the tissues were incubated with 3\% hydrogen peroxide for blocking the endogenous peroxidase activity, and then they were washed with pH7.4 PBS. To block the unspecified protein, 5\% FBS which contains $0.25 \%$ Triton $\mathrm{X}-100$ was used. Then each of the TGF- $\beta 1$, p38 MAPK, ERK-1 monoclonal antibodies (Santa Cruz Biotechnology, Dallas, TX, USA) were applied. After being washed, each monoclonal antibody were incubated using anti mouse HRP conjugated for 40 minutes, then washed again with PBS pH7.4. Diamino benzidine (DAB) was applied to each antibody and incubated for 10 minutes. Lastly, it was counterstained by using Meyer Hematoxylin before being washed and covered with glass. ${ }^{13,14}$

\section{Immunohistochemistry Evaluation}

The TGF- $\beta 1$, p38 MAPK, and ERK-1 immunohistochemical expressions were examined on 20 fields per slide for each sample under a light microscope with 1000x magnification, cross-checked by two trained examiners under supervision, and captured with Nikon camera AW100 manufactured in Ayutthaya, Thailand. The positive cell was the one that stained brown in colour. As there are many brown colours 
spectrums, we refer the brown colour as written in the Santa Cruz Biotechnology database (www.scbt.com). Then the average number of the positive cell per field for every samples was counted..$^{13,14}$

\section{Data Analysis}

Statistical analysis was performed by SPSS ver. 25 (IBM Coorporation, Armonk, NY, USA) for Pearson correlation test, to see the correlation between each protein, age and gender.

\section{Results}

Paraffin blocks from 30 subjects were selected. All subjects were those with non-syndromic cleft lip without cleft palate. Immunohistochemical expression of TGF- $\beta 1$, p38 MAPK and ERK-1 were observed for every sample. As shown in Figure 1 and Table 1 , the highest average of TGF- $\beta 1$ immunostaining was 13 per field of view, the lowest average was 2 per field of view. The highest average of p38 MAPK immunostaining was 16 per field of view, while the lowest average was 1. The average ERK-1 expression ranged from 1-4 per field of view. After being calculated, the mean average expression of TGF- $\beta 1$ from 30 samples was 5 $(2.5 \pm \mathrm{SD})$ per field of view, for p38 MAPK was $8(3.6 \pm \mathrm{SD})$, and ERK- 1 was $2(0.8 \pm \mathrm{SD})$. Figure 2 showed the TGF- $\beta 1$, p38 MAPK and ERK-1 expression of cleft lip tissue.

Pearson correlation test was performed to see the correlation between each protein with age and gender (Table 2). It was found that only TGF- $\beta 1$ and p38 MAPK had correlation with significance $p<0.05$

\section{Discussion}

Based on our knowledge, there were no study observing the normal value for each protein in normal person, previous study compared proteins in cleft lip patients only. ${ }^{15}$ Therefore, in this study we compared the expression next to each other.

In our study, we found that p38 MAPK has the highest mean of protein expression followed by TGF- $\beta 1$, and ERK-1. The expression of p38 MAPK and TGF- $\beta 1$ is more than two times higher than ERK-1. This is consistent with the previous study, as the activation of the p38 MAPK could lead to malformation of the palate area of mice, as the TGF- $\beta 1$ also considered highly expressed we suggest the mechanism in human is the same as in mice, which MAPK pathway is activated by TGF- $\beta$ signalling. ${ }^{10,16}$

ERK-1 on other side considered as low in expression, this also similar as the other study on mice as the ERK$1 / 2$ inactivation could induce cleft palate phenomenon. ${ }^{17}$ We suggest the mechanism is the same between in mice and human. Our study findings conclude that there all the three proteins play role in development of the cleft lip in human, and we suggest that there is no single cause of the development of cleft lip in molecular level.

We found no significance correlation between each of protein expression with age and gender. As the formation of maxillofacial area happens during intrauterine process, environmental factors such as alcohol consumption, smoking and lack of nutritional consumption during pregnancy may be more related in the developmental of cleft lip. ${ }^{2}$

\section{Protein Expression}

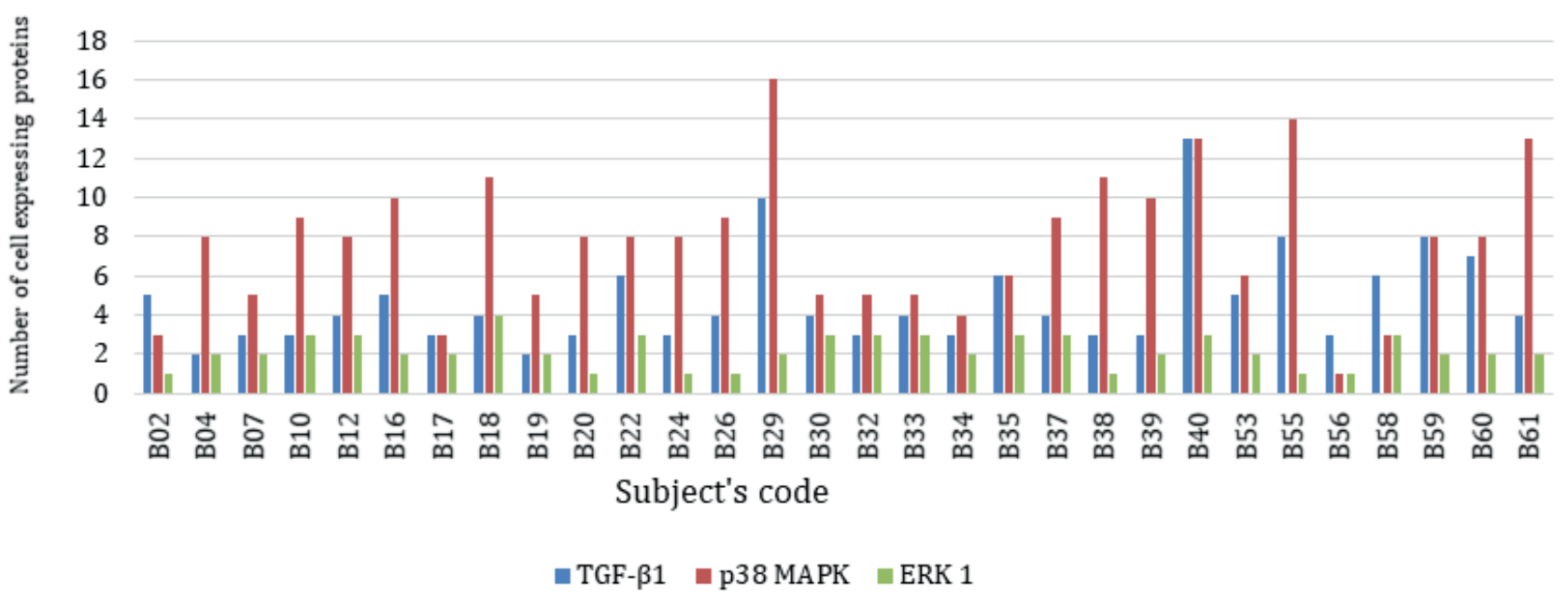

Figure 1. The expression of TGF- $\beta 1$, p38 MAPK, and ERK-1. 
Table 1. List of the cleft lip sample with gender, age, and proteins expression.

\begin{tabular}{|c|c|c|c|c|c|}
\hline \multirow{2}{*}{ Sample } & \multirow{2}{*}{ Gender } & \multirow{2}{*}{$\begin{array}{c}\text { Age } \\
\text { (Years Old) }\end{array}$} & \multicolumn{3}{|c|}{ Protein Expression } \\
\hline & & & TGF- $\beta 1$ & p38 MAPK & ERK-1 \\
\hline B02 & $\mathrm{M}$ & 1.5 & 5 & 3 & 1 \\
\hline B04 & $\mathrm{F}$ & 12 & 2 & 8 & 2 \\
\hline B07 & $\mathrm{F}$ & 0.4 & 3 & 5 & 2 \\
\hline $\mathrm{B} 10$ & M & 23 & 3 & 9 & 3 \\
\hline B12 & $\mathrm{F}$ & 18 & 4 & 8 & 3 \\
\hline B16 & $\mathrm{F}$ & 6 & 5 & 10 & 2 \\
\hline B17 & $\mathrm{F}$ & 27 & 3 & 3 & 2 \\
\hline B18 & $\mathrm{F}$ & 16 & 4 & 11 & 4 \\
\hline B19 & M & 14 & 2 & 5 & 2 \\
\hline B20 & M & 5 & 3 & 8 & 1 \\
\hline B22 & $\mathrm{F}$ & 7 & 6 & 8 & 3 \\
\hline B24 & $\mathrm{F}$ & 7 & 3 & 8 & 1 \\
\hline B26 & $\mathrm{F}$ & 7 & 4 & 9 & 1 \\
\hline B29 & $\mathrm{F}$ & 17 & 10 & 16 & 2 \\
\hline $\mathrm{B} 30$ & M & 6 & 4 & 5 & 3 \\
\hline B32 & $\mathrm{M}$ & 4 & 3 & 5 & 3 \\
\hline B33 & $\mathrm{F}$ & 29 & 4 & 5 & 3 \\
\hline B34 & $\mathrm{M}$ & 4 & 3 & 4 & 2 \\
\hline B35 & $\mathrm{M}$ & 10 & 6 & 6 & 3 \\
\hline B37 & $\mathrm{M}$ & 2 & 4 & 9 & 3 \\
\hline B38 & $\mathrm{M}$ & 14 & 3 & 11 & 1 \\
\hline B39 & $\mathrm{F}$ & 12 & 3 & 10 & 2 \\
\hline B40 & $\mathrm{M}$ & 3 & 13 & 13 & 3 \\
\hline B53 & $\mathrm{F}$ & 2 & 5 & 6 & 2 \\
\hline B55 & F & 1 & 8 & 14 & 1 \\
\hline B56 & $\mathrm{M}$ & 1 & 3 & 1 & 1 \\
\hline B58 & $\mathrm{M}$ & 1 & 6 & 3 & 3 \\
\hline B59 & $\mathrm{M}$ & 17 & 8 & 8 & 2 \\
\hline B60 & $\mathrm{M}$ & 27 & 7 & 8 & 2 \\
\hline B61 & $\mathrm{M}$ & 15 & 4 & 13 & 2 \\
\hline
\end{tabular}

M: Male; F: Female.

Table 2. Pearson correlation between protein expression with gender and age.

\begin{tabular}{lccccc}
\hline & Gender & Age (Years Old) & TGF- $\beta$ & p38 1 MAPK & ERK-1 \\
\hline Gender & - & 0.399 & 0.795 & 0.197 & 0.887 \\
Age (Years Old) & 0.399 & - & 0.687 & 0.524 & 0.225 \\
TGF- $\beta 1$ & 0.795 & 0.687 & - & $0.006^{* *}$ & 0.452 \\
p38 MAPK & 0.197 & 0.524 & $0.006^{* *}$ & - & 0.984 \\
ERK-1 & 0.887 & 0.225 & 0.452 & 0.984 & - \\
\hline
\end{tabular}

**Correlation is significant at the $p<0.05$ level (2-tailed). 

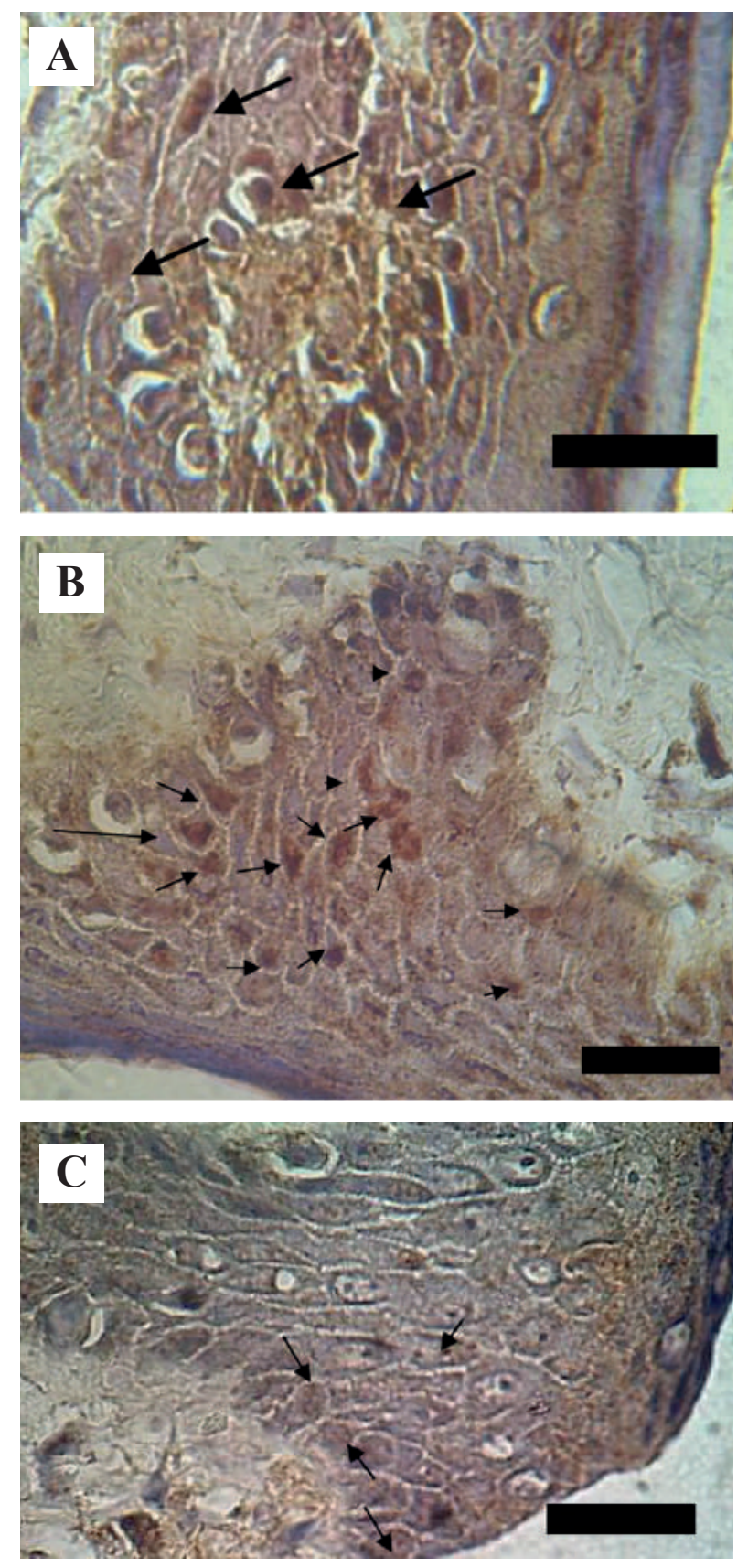

Figure 2. TGF- $\beta 1$, p38 MAPK and ERK-1 expression of cleft lip tissue. A: TGF- $\beta 1$; B: p38 MAPK; C: ERK-1. Black arrow indicates the protein expression in a cell. Under light microscope Nikon YS 100 with 1000x magnification. Picture taken with camera Nikon AW100. Black bar :10 $\mu$ m.

This study had some limitation, including the calculation of the protein expression was done manually, due to minimal material available to count the cell expression during the study.

\section{Conclusion}

Expression of $\mathrm{p} 38$ MAPK and TGF- $\beta 1$ are higher than ERK-1, suggesting that $\mathrm{p} 38 \mathrm{MAPK}$ is in the same signalling pathway as TGF- $\beta 1$, while ERK-1 is lower, as its role as antiapoptotic. This is consistent with several previous studies showing that all proteins took part in the development of cleft lip or craniofacial development. Further study needs to be conducted to determine which protein plays the bigger role.

\section{Acknowledgements}

The authors give thanks to Alor Hospital, Larantuka Hospital, Kupang General Hospital and Brawijaya Biochemistry laboratory for the contribution of this study.

\section{References}

1. Wójcicki P, Koźlik M, Wójcicka K. Genetic factors in selected complex congenital malformations with cleft defect. Adv Clin Exp Med. 2016; 25(5): 977-87.

2. Saleem K, Zaib T, Sun W, Fu S. Assessment of candidate genes and genetic heterogeneity in human non syndromic orofacial clefts specifically non syndromic cleft lip with or without palate. Heliyon. 2019; 5(12): e03019. doi: 10.1016/j.heliyon.2019.e03019.

3. Stoll C, Mengsteab S, Stoll D, Riediger D, Gressner AM, Weiskirchen R. Analysis of polymorphic TGFB1codons 10, 25, and 263 in a German patient group with non-syndromic cleft lip, alveolus, and palate compared with healthy adults. BMC Medical Genetics. 2004; 5(1): 15. doi: 10.1186/1471-2350-5-15.

4. Wahyuni LK. Sumbing Bibir dan Lelangit: Manajemen Fungsi Bicara. [n.p.]: CV Read Octopus; 2018.

5. Sjamsudin E, Maifara D. Epidemiology and characteristics of cleft lip and palate and the influence of consanguinity and socioeconomic in West Java, Indonesia: a five-year retrospective study. Int J Oral Maxillofac Surg. 2017; 46(Suppl 1): 69. doi: 10.1016/j. ijom.2017.02.251.

6. Tan J, Wu J. Current progress in understanding the molecular pathogenesis of burn scar contracture. Burns Trauma. 2017; 5: 14. doi: 10.1186/s41038-017-0080-1.

7. Koivisto L, Heino J, Häkkinen L, Larjava H. Integrins in wound healing. Adv Wound Care. 2014; 3(12): 762-83.

8. Rullo R, Gombos F, Ferraraccio F, Farina A, Morano D, Festa VM, et al. TGF 33 expression in non-syndromic orofacial clefts. Int $\mathrm{J}$ Pediatr Otorhinolaryngol. 2006; 70(10): 1759-64.

9. Rullo R, Gombos F, Ferraraccio F, Farina A, Morano D, Festa V, et $a l$. TGF alpha has low protein expression in nonsyndromic clefts. J Craniofac Surg. 2007; 18(6): 1276-80.

10. Iwata J, Hacia JG, Suzuki A, Sanchez-Lara PA, Urata M, Chai Y. Modulation of noncanonical TGF- $\beta$ signaling prevents cleft palate in Tgfbr2 mutant mice. J Clin Investig. 2012; 122(3): 873-85.

11. Vantaggiato C, Formentini I, Bondanza A, Bonini C, Naldini L, Brambilla R. ERK1 and ERK2 mitogen-activated protein kinases affect Ras-dependent cell signaling differentially. J Biol. 2006; 5(5): 14. doi: $10.1186 /$ jbiol38. 
12. Parada C, Han D, Grimaldi A, Sarrion P, Park SS, Pelikan R, et al. Disruption of the ERK/MAPK pathway in neural crest cells as a potential cause of Pierre Robin sequence. Development. 2015; 142(21): 3734-45.

13. Pizem J, Coer A. Detection of apoptotic cells in tumour paraffin sections. Radiother Oncol. 2003; 37(4): 225-32.

14. Soini Y, Pääkkö P, Lehto V-P. Histopathological evaluation of apoptosis in cancer. Am J Pathol. 1998; 153(4): 1041-53.

15. Sidhom E, Pilmane M. Detection of TGF- $\beta 1$, HGF, IGF-1 and IGF-
$1 \mathrm{R}$ in cleft affected mucosa of the lip. Open Dermatol J. 2017; 11(1): 46-52.

16. Xu X, Han J, Ito Y, Bringas P, Deng C, Chai Y. Ectodermal Smad4 and 38 MAPK are functionally redundant in mediating TGF- $\beta /$ BMP signaling during tooth and palate development. Dev Cell. 2008; 15(2): 322-9.

17. Yamamoto T, Cui XM, Shuler CF. Role of ERK1/2 signaling during EGF-induced inhibition of palatal fusion. Dev Biol. 2003; 260(2): 512-21. 